\title{
Can biogas, generated from cattle waste reduce negative externalities? A case of study in argentina
}

\author{
Recibido: 26 de febrero de 2020 - Aprobado: 15 de abril de 2020 \\ https://doi.org/10.22395/seec.v23n54a7 \\ Gabriela Cristiano* \\ Claudia Buitrago**
}

\begin{abstract}
Lately, Argentina has been promoting renewable energies by implementing several programs. Agroindustrial activities generate organic waste, which could be treated to mitigate the negative externalities it causes. In this work the results proposed regarding the volume of biogas generation from waste were estimated for a firm in the Corfo region in the province of Buenos Aires. We present an alternative to reduce negative externalities and improve environment through the transformation of biomass into caloric energy, considering the case of a multiproduct firm, in which waste can be the input to produce a new output (biogas and biofertilizer). We determined that, from the effluent generated by 500 heads of cattle, it is possible to obtain $10.125 \mathrm{~m}^{3}$ of biogas/month, which could be sold or used by the agrarian firm for self-consumption, diminishing its costs.
\end{abstract}

\section{KEYWORDS}

Negative externalities; environmental impact; livestock; biogas.

\section{JEL CLASSIFICATION}

$17 \mathrm{Q}, \mathrm{Al}, \mathrm{D} 2, \mathrm{H} 23$

\section{CONTENT}

Introduction; 1. Economic analysis of negative impacts generated by productive activities; 2. Argentina's bioenergy: Legal background; 3. Carbon balance in the greenhouse effect; 4. Anaerobic fermentation: $\mathrm{CH}_{4}$ and $\mathrm{CO}_{2} ; 5$. Biogas production process; 6 . Study case of an agrarian firm in the Corfo region; Conclusions; Bibliography.

\footnotetext{
Investigation article based on the joint research The process of generation of biogas (2018-2019), corresponding to these investigation groups: 1 - Economic productive and social development linked to added value: 2015-2019 Departamento de Economía and Instituto de Investigaciones Económicas y Sociales del Sur (IIESS) (Conicet-UNS) UNS financed this work. 2- Rhabdomyosarcoma and normal skeletal muscle: molecular mechanisms regulated by 1,25 dihydroxy-vitamin D3 and its analogue EB 1089. 2017-2020. Instituto de Investigaciones Biológicas y Biomédicas del Sur (Inbiosur) (Conicet-UNS). Conicet-UNS finance this work.

.. Degree in Economics, Universidad Nacional del Sur, Bahía Blanca, Argentina. Master in Agrarian Economy \& Rural Administration, Universidad Nacional del Sur, Bahía Blanca, Argentina. Ph. D in Economics, Universidad Nacional del Sur, Bahía Blanca, Argentina. Adjunct Professor, Universidad Nacional del Sur, Bahía Blanca, Argentina. Researcher in the Instituto de Investigaciones Económicas y Sociales del Sur (IIESS). E-mail: gcristiano@ uns.edu.ar. Orcid: https://orcid.org/0000-0002-1633-4406

... Degree in Biology, Universidad Nacional del Sur, Bahía Blanca, Argentina. Ph. D in Biological Sciences, Universidad Nacional del Sur, Bahía Blanca, Argentina. Independent Researcher of Conicet, Assistant Professor of the Universidad Nacional del Sur, Bahía Blanca, Argentina. E-mail: cbuitrag@criba.edu.ar. Orcid: https://orcid. org/0000-0002-3090-4700
} 


\section{¿PUEDE EL BIOGÁS GENERADO A PARTIR DE RESIDUOS DE GANADO REDUCIR LAS EXTERNALIDADES NEGATIVAS? UN CASO DE ESTUDIO EN ARGENTINA}

\section{RESUMEN}

Últimamente, Argentina promueve la producción de energías renovables mediante varios programas nacionales. Las actividades agroindustriales generan residuos orgánicos que se podrín a un tratamiento para mitigar las externalidades negativas que causan. En este trabajo se estimaron los resultados propuestos con respecto al volumen de generación de biogás a partir de residuos para establecimientos en la región de Corfo en la provincia de Buenos Aires. Se presenta aquí una alternativa para reducir las externalidades negativas y mejorar el medio ambiente a través de la transformación de la biomasa en energía calórica mediante el estudio de caso de una empresa multiproducto, en la que los residuos pueden ser la entrada para producir una nueva salida (biogás y biofertilizante). A partir del efluente generado por 500 cabezas de ganado se determina que es posible obtener 10,125 $\mathrm{m}^{3} \mathrm{de}$ biogás/mes, que la empresa agraria podría vender o utilizar para autoconsumo, con lo cual disminuiría sus costos.

\section{PALABRAS CLAVES}

Externalidades negativas; impacto medioambiental; ganadería; biogás

\section{CLASIFICACIÓN JEL}

$17 \mathrm{Q}, \mathrm{Al}, \mathrm{D} 2, \mathrm{H} 23$

\section{CONTENIDO}

Introducción; 1. Análisis económico de los impactos negativos generados por las actividades productivas; 2. La bioenergía de Argentina: antecedentes legales; 3 . El balance de carbono en el efecto invernadero; 4. La fermentación anaerobia: $\mathrm{CH} 4$ y CO2; 5. El proceso de producción de biogás; 6 . Estudio de caso particular: una empresa agraria de la región de Corfo; Conclusiones; Bibliografía.

\section{O BIOGÁS GERADO PELOS RESÍDUOS PECUÁRIOS É CAPAZ DE REDUZIR AS EXTERNALIDADES NEGATIVAS? UM ESTUDO DE CASO NA ARGENTINA}

\section{RESUMO}

Ultimamente, a Argentina vem promovendo energias renováveis ao implementar diversos programas. Atividades agroindustriais geram resíduos orgânicos, que poderiam ser tratados para mitigar as externalidades negativas causadas por eles. Neste trabalho, foram estimados os resultados propostos com respeito ao volume de geração de biogás a partir de resíduos em uma empresa na região do Corfo, na província de Buenos Aires. Apresentamos uma alternativa para reduzir as externalidades negativas e melhorar o meio ambiente mediante a transformação de biomassa em energia calórica, considerando o caso de uma empresa multiproduto, na qual os resíduos podem ser a matéria-prima para elaborar novos produtos (biogás e biofertilizante). Determinamos que, a partir do material gerado por 500 cabeças de gado, é possível obter 10,125 m3 de biogás/mês, que poderiam ser vendidos ou utilizados pela empresa agrária para o consumo próprio, o que diminuiria os gastos.

\section{PALAVRAS CHAVES}

Externalidades negativas; impacto ambiental; gado; biogás.

\section{JEL CLASSIFICATION}

$17 \mathrm{Q}, \mathrm{A} 1, \mathrm{D} 2, \mathrm{H} 23$

\section{CONTEÚDO}

Introdução; 1. Análise econômica dos impactos negativos gerados pelas atividades produtivas; 2. Bioenergia na Argentina: contexto jurídico; 3. Balanço do carbono no efeito estufa; 4. Fermentação anaeróbica: $\mathrm{CH} 4$ e $\mathrm{CO} 2 ; 5$. Processo de produção do biogás; 6. Estudo de caso de uma empresa agrária na região do Corfo; Conclusões; Bibliografia. 


\section{INTRODUCTION}

Currently, fossil fuels and nuclear energy provide more than $80 \%$ of the energy used in the world every year. But reserves of fossil fuels are limited and, to a greater or lesser degree, they are pollutants. Since the mid-twentieth century, with population growth, extension of industrial production and massive use of technologies began to raise concern about the depletion of oil reserves and environmental deterioration.

On the other hand, the alarm due to global environment deterioration has begun to manifest towards the end of the 1960's. This issue gradually became part of the agenda of the public sector and of numerous international organizations. This led to consider in greater depth the environmental impacts that bring productive activities inserted in a territory. Air, soil and water contamination threaten the system's productivity, affecting the well-being of future generations and its sustainability

As proposed by Recalde (2012), sustainable development implies coordinated evolution of economic, social, political and environmental dimensions. Gruber, Hilbert and Sheimberg (2010) and Bragachini et al. (2014) argue that this highlights the urgent need to implement an efficient action plan to carry out proper management and treatment of organic waste generated by various productive activities, with the possibility of obtaining sub-products that are harmless to the environment and that in turn, can have a market value, such as biogas and bio fertilizers. These sub-products could also be used intra-firm and represent savings in energy costs.

According to Di Paola (2013), negative environmental consequences of fossil fuels and the uncertainty about oil and gas constant supply have stimulated the search for biofuels as alternative energies; that is, energy sources that can also be considered as renewable. In this case, biomass constitutes an interesting potential in the field of the economic cycle. Since then, development of alternative energies based on renewable and less polluting natural resources, such as sunlight, tides, water and biomass, has been promoted.

One way to achieve a path of development with the perspective of protecting the environment is through organic waste treatment in biodigesters. In this paper, we present the case study of a representative firm, in which biomass from livestock waste is transformed into bioenergy, taking advantage of public policies that promote use of energies based on biomass in the Argentinian context.

The aim of this paper is to present a new way to reduce the agrarian sector's negative externalities . It consists of turning the one-product firm into a multiproduct one which now produces caloric energy, in addition to meat. This will not only impact environment but also the benefits. 
In section 1 we present an economic analysis of negative impacts generated by productive activities. In section 2 we briefly describe some aspects related to the legal background about bioenergy in Argentina to stress the importance it has for the country. Then, in sections 3, 4 and 5 the greenhouse effect, anaerobic fermentation and biogas production process are described to put the reader in context about this new technology that contributes to reduce negative environmental impacts caused by certain productive activities. Finally, in section 6 we present a case study of an agrarian firm in Corfo region, in the south of Buenos Aires province, Argentina.

\section{ECONOMIC ANALYSIS OF NEGATIVE IMPACTS GENERATED BY PRODUCTIVE ACTIVITIES}

Following Mas-Colell, Whinston and Green (1995), neoclassical economic theory addresses this issue by studying negative production externalities. For this reason, it is necessary to understand and incorporate the concept of environment in economic analysis. By one hand, the environment is a dual space in which individuals carry out all their productive activities and take from it the necessary resources to transform them into final products with a greater or lesser degree of added value. However, on the other hand, that same environment is what receives all the waste generated by both producers and consumers.

The above described gives rise to the emergence of environmental economics, which is based on neoclassical theory. Central issues of environmental economics are: The treatment of externalities (in which monetary valuation of environmental benefits and costs is analyzed), and the study related to the problem of non-renewable resources depletion linked to the issue of optimal intergenerational allocation.

Aguilera Klink and Alcántara (2011) mention that:

The generalized awareness of the environmental repercussions of economic activity has revealed the need to include, in the framework of economic decision-making, all the problems derived from the intimate relations between economy and ecology, that the standard economy has reduced the narrow corset of externalities. (p. 6)

In view of this, it is possible to say that there is an externality when a certain activity, whether production or consumption, produces an indirect effect (positive or negative) on other production or consumption activities that is not reflected through the market price system. In this case, market prices do not fully manifest the costs (or benefits) associated with activities carried out by producers or consumers. According to Mas-Colell, Whinston and Green (1995), these prices appear distorted, since they do not include all the costs or real benefits for society, which leads to an inadequate allocation of resources. In the presence of externalities, the market 
fails, and a loss of welfare is generated because it tends to produce more or less than what would be optimal.

Arthur Pigou (1920) is considered precursor of Welfare Economy and main pioneer of the environmental movement. He distinguished the private costs of social, as well as private and social benefits, raising the problem of externalities from a unilateral perspective; this implies that an agent -producer or consumer-causes a loss or benefit to another and for this reason, must be compensated or penalized. According to Pigou, the State is the one that can solve these externalities, which (given a certain legal framework), through the collection on taxes (called Piguvian Taxes) can prohibit or decrease the production of the goods in question.

As an example, it is worth mentioning that the State could sanction a company that pollutes through the application of a tax, in order to force it to internalize this negative externality. According to Pigou's proposal the State intervenes and regulates the activity by charging a tax on the company that originates the negative externality, raising its cost by internalizing the external effect caused by producing a certain level of product. This fact means that the firm, faced with higher costs, is forced to reduce its production levels.

The situation described above can be observed in graphic 1 . In the market, the demand (D) reflects the marginal social benefit (MSB). The supply curve (MC) only considers private cost, but it does not consider marginal social cost (MSC). Marginal external cost is given by the curve MEC. All economic damages generated by the externality can be expressed through the external cost (EC). The efficient market equilibrium will occur when the MSC is considered, producing $\mathrm{Q}^{*}$ at the price $\mathrm{P}^{*}$.

\section{Graphic 1. Negative externalities in production}

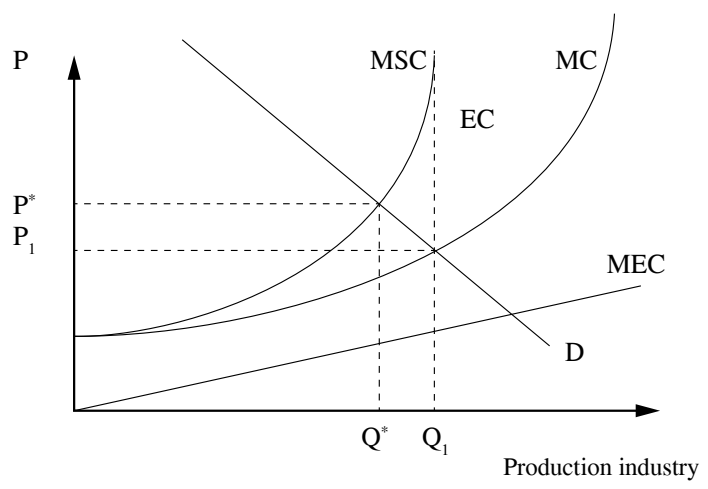

Source: Pindyck, Rubinfeld y Beker (2000, p. 447). 
The other general approach to possible solutions to the problem of externalities comes from the general proposal enunciated by Ronald Coase (1960), popularized later by George Stigler under the name of Coase's Theorem. It postulates that it will always be possible to obtain -under certain conditions-, through negotiation, an optimal balance between needs of society and inevitable externalities generated in production -consumption-, indispensable to satisfy them. Coase advances in the analysis and, unlike Pigou, considers that the problem of externalities can become a reciprocal problem, where both parts are involved.

According to Aguilera Klink and Alcántara (2011), Coase argues that the problem of benefits and external costs does not lie specifically in the fact that they are external, but in property rights -which in this case are imprecise and indeterminate- and transaction costs, which are high. If these property rights are clearly defined, the number of parts involved is reduced and the transaction costs are low, it could be concluded that the transactions are efficient. In this way, externalities would be internalized.

This paper proposes another way to reduce negative impacts on the environment that consists of carrying out a treatment of organic waste generated by productive activities. We propose a new way to treat negative externalities by transforming a single product firm into a multiproduct firm. In the case study we present a firm dedicated to the production of meat under feedlot modality, it can use the organic waste as an input to produce new output, such as biogas and biofertilizer. According to Pordomingo (2014), the activity's negative impacts on the environment (such as soil, water and air) can be mitigated.

\section{ARGENTINA'S BIOENERGY: LEGAL BACKGROUND}

The National Institute of Agricultural Technology (INTA for its acronym in Spanish) positions bioenergy within its agenda through its national programs. Several decades ago, INTA started developing studies related to bioenergetic issues, around management of animal waste to obtain biogas. Due to that, the National Program of Bioenergy and the Cooperation Network of Agricultural Public Policies emerged in 2011, dedicated to study public policies in agroenergy that contribute to environmental balance and poverty mitigation. The program aims to promote firms that can ensure an energy supply, based on renewable sources, in order to increase participation of bioenergy within the national energy matrix. Hilbert et al. (2011) consider that the program is linked to various organizations, whether national or foreign, which helps to address the issues related to energy demand more efficiently. 
Under the aforementioned program, INTA chairs the Agriculture Committee of the Global Methane Initiative, which is a mixed public-private partnership created in 2004. The proposed goal is -through diverse projects generation- to reduce the amount of methane emitted to the environment, which is one of the most important gases responsible for the greenhouse effect. This organization is composed by 36 countries, and these are the ones that contribute with more than $65 \%$ of global emissions. Hilbert et al. (2011) argue that the association has focused on the development of projects from four sources: agriculture, landfills, coal mines and oil and gas sector. In addition, there is a Project for the Promotion of Energy Derived from Biomass (Probiomasa for its acronym in Spanish), its's mission is to transform animal and vegetable organic waste into biogas in order to achieve greater energy diversification. It was launched in October 2012 and includes the Ministry of Agriculture, Secretariat of Energy and United Nations Organization for Food and Agriculture (FAO, for its acronym in Spanish).

Three laws dealing with bio fuels have been enacted in Argentina in recent years:

1. Law $N^{\circ} 26093$ (2006). Refers to the sustainable production and use of biofuels.

2. Law $N^{\circ} 26190$ (2006). Refers to the promotion for the use of renewable energy sources destined to electric energy production through economic incentives.

3. Law $\mathrm{N}^{\circ} 27191$ (2015). Refers particularly to achieving a contribution from renewable energy sources to reach twenty percent $(20 \%)$ of national electricity consumption by December 31 2025.

\section{CARBON BALANCE IN THE GREENHOUSE EFFECT}

Some gases present in the atmosphere that contribute to rise air temperature are called greenhouse gases (GHG). The most important are chlorofluorocarbons (CFC), carbon dioxide $\left(\mathrm{CO}_{2}\right)$, nitrous oxide $\left(\mathrm{N}_{2} \mathrm{O}\right)$, water vapour and methane $\left(\mathrm{CH}_{4}\right)$. Increases in temperature occur because gases absorb part of the infrared radiation which are re-emitted by planet Earth. Johnson and Johnson (1995) argue that this phenomenon is good to give the right temperature that allows life on Earth; however, the increase in the amount of these gases detached from human activities (livestock, transport, industry, among others) generates an alarm due to global warming phenomenon. For the special case of $\mathrm{CH}_{4}$ it is known that the amount of this gas contained in polar ice was stable until a hundred years ago, but began to increase gradually and today it is approximately 2.5 times higher. 
Rodhe described in 1990 that, although there are 200 times less $\mathrm{CH}_{4}$ than $\mathrm{CO}_{2}$ in the atmosphere, methane contributes $18 \%$ of the greenhouse effect, compared to $49 \%$ contributed by $\mathrm{CO}_{2}$ (Rodhe, 1990). It should also be considered that the average life in the atmosphere of $\mathrm{CH}_{4}$ (about 20 years) is less than that of $\mathrm{CO}_{2}$ that can reach 200 years, although $\mathrm{CH}_{4}$ is 60 times more powerful than $\mathrm{CO}_{2}$ to retain heat in the atmosphere (Chatelier and Verité, 2003). It must be taken into account that a part of $\mathrm{CO}_{2}$ is converted into $\mathrm{CH}_{4}$ by microbial fermentation, which is what happens in the digestive system of animals and also in some types of soils.

In 2019, Argentina presented the Third Biennial Report for the United Nations Organization. The category "Energy Industries" (based on the use of natural gas) is first and contributes with $53 \%$ of $\mathrm{CO}_{2}$ emissions in the national greenhouse gases (GHG) inventory list. The second most important category is "Cattle Enteric Fermentation" (mainly due to meat and milk) contributing with $20 \%$ of total GHG with $\mathrm{CH}_{4}$. It is important to note that Argentina established an absolute goal of not exceeding the net emission of 483 million tons of carbon dioxide equivalent $\left(\mathrm{MtCO}_{2} \mathrm{e}\right)$ in 2030 (Secretaría de Ambiente y Desarrollo Sustentable, 2019).

\section{ANAEROBIC FERMENTATION: $\mathrm{CH}_{4}$ AND $\mathrm{CO}_{2}$}

The greenhouse effect caused by livestock is explained because ruminant animals, through their excreta (eruptions and mainly manure), release gases into the atmosphere, including $\mathrm{CO}_{2}$ (carbon dioxide) and $\mathrm{CH}_{4}$ (methane), which deteriorate the ozone layer and contribute to global warming. Ruminants are herbivores whose main foods are plants that contain fibrous carbohydrates (complex polysaccharides such as cellulose). However, these animals do not have enzymes to digest them.

The microorganisms present in the rumen, such as bacteria, protozoa and fungi, are the ones that allow the ruminant to digest the cellulose in food when fermenting. These animals are benefited because thanks to these processes they can also: take advantage of proteins and sources of non-protein nitrogen, for their conversion into microbial protein, to synthesize water-soluble vitamins, use final products of fermentation, particularly volatile fatty acids (VFA) and the nutrients contained in the cell bodies of microorganisms, incorporated by digestion in the abomasum and small intestine.

Cuauhtémoc Nava Cuéllar and Antonio Díaz Cruz (2001) explain that, through ruminal fermentation, the ruminant obtains the necessary nutrients for the maintenance of vital biological functions. Bacteria are the most abundant microorganisms in the rumen and there are at least 28 functionally important species, which are 
grouped according to their activity. Most bacteria are strict anaerobes that cannot survive in the presence of oxygen; however, facultative organisms are also present.

The population of rumen protozoa is lower than bacteria ( 1 million per $\mathrm{ml}$ of ruminal content), but as they have a larger individual volume although their number is lower compared to bacteria, they give rise to a cell mass similar to the mass of bacteria. Protozoa consume and metabolize soluble sugars, and hydrolyse bacteria to use them as a substrate, thereby limiting bacterial growth. More than $8 \%$ of the rumen's microbial biomass are fungi and ferment cellulose. Due to ruminal fermentation, different gases are produced -about 30-50 litres / hour in an adult bovine and 5 in a sheep- eliminated through burping. These gases are $60-70 \% \mathrm{CO}_{2}$ and $30-40 \% \mathrm{CH}_{4}$.

Methanogenic anaerobic bacteria are those that carry out the production process of $\mathrm{CH}_{4}$, which they use for their generation, among other gases, hydrogen $\left(\mathrm{H}_{2}\right)$ and $\mathrm{CO}_{2}$. If this type of digestion occurs under aerobic conditions -which does not happen- pyruvate would be transformed into mitochondria generating $\mathrm{CO}_{2}, \mathrm{H}_{2} \mathrm{O}$ (water) and ATP (adenosine tri phosphate) through Krebs cycle, respiratory chain and ATPase (adenosine tri phosphatise), and this would restore the NAD oxidized (nicotin adenin dinucleotide oxidized). But fermentative digestion is a highly anaerobic and reducing system, so a different mechanism for the restoration of NAD is necessary. If this mechanism did not exist, all oxidized factors present would be reduced rapidly and bacterial metabolism would stop.

Because oxygen is not found in the rumen, another compound must serve as the electron sink for the oxidation of enzymatic cofactors. In fermentative digestion, pyruvate captures electrons, suffering an even greater reduction in order to provide the necessary material for regenerating the NAD, and an additional production of ATP. In addition, $\mathrm{CO}_{2}$ can be reduced to form $\mathrm{CH}_{4}$ by accepting electrons for NAD and FAD (flavin adenine dinucleotide) regeneration. This transforming process of pyruvate gives rise to the terminal products of fermentative digestion of carbohydrates, the so-called volatile fatty acids (VFA). The equation of ruminal fermentation is summarized in:

Carbohydrates + proteins $=$ microbiota + VFA $+\mathrm{NH}_{3}+\mathrm{CH}_{4}+\mathrm{CO}_{2}$

Summing up: "Anaerobic digestion is the biological process by which the organic matter is decomposed to give rise to a combustible gas (biogas), mainly formed by methane $\left(\mathrm{CH}_{4}\right)$ in 55-70 \% and carbon dioxide $\left(\mathrm{CO}_{2}\right)$ ") (Flotats, 2010, p. 23$)$. 


\section{BIOGAS PRODUCTION PROCESS}

Organic matter (manure) anaerobic decomposition process, which occurs in the total absence of oxygen or nitrates, produces a fuel gas composed of a high percentage of methane gas. In this type of processes, the fuel gas and the anaerobic environment jointly produce the transformation and purification of organic matter, which leads to the generation of this gas. Bonilla Cárdenas and Lemus Flores (2012) argue that while there are ways to reduce the amount of biogas produced by livestock, strategies that can be used must be comprehensive and carefully designed at any planning level and are usually very expensive.

There are no simple methodologies (easy to implement and standardize in any laboratory) to carry out studies on methane production in vitro or in vivo. Thus it is much more convenient to use the generated biogas, taking it out of the atmosphere and allowing energy to be generated from it. According to Varnero Moreno (2011), this is done in closed facilities -specially designed to optimize the process -called bio digesters, which will be detailed afterwards. A biogas generator system is an installation whose operation provides energy. This simple technique allows to supply - partially or totally- energy demand in rural areas, contributes to reduce deforestation originated by indiscriminate felling to obtain firewood, and manages to recycle waste from agricultural activities.

Sogari, Manfred and Busso (2000), as well as collaborators presented to National University of Northeast authorities, a design project of a bio digester in the AgroTechnical School, that allows to obtain methane gas using animal excrement (from cows and pigs) as raw material to air condition the pavilions. In addition, they foresaw the installation of an underground energy storage system, which allowed cooling during the summer days. Years later, taking into account studies carried out in avian production, Flotats (2010) exposed that the changes in droppings in a farm management and their treatment resulted in an improvement of the ships air quality, a reduction of mortality by $57 \%$, an increase in daily weight gain of $11 \%$, increased conversion rates by $5.4 \%$ and an increase in sales of live weight of $5.6 \%$.

According to Flotats (2010), treatment of animal excreta after an anaerobic digestion process contributes to:

1. Reduce smells. This is due to volatile organic compounds decomposition, which are transformed into methane and carbon dioxide during controlled anaerobic digestion; otherwise, they would be emitted into the atmosphere. These gases can be used to obtain gas and electricity.

2. Reduce the content of insect eggs and larvae, weed seeds and pathogenic microorganisms that are usually found in excrement. 
3. Reduce the viscosity and size of the particles. This has a positive effect on the infiltration of residues obtained from anaerobic digestion in the soil, since it reduces the loss by volatilization of ammoniac nitrogen during agricultural applications. This makes digested digests suitable for fertilization, with no subsequent harmful effects (if it is compared with the use of excreta without prior treatment). It should be mentioned that this is possible because, in the process of anaerobic digestion, gaseous nitrogen is transformed into ammonia and, after being dissolved in water, it is available to the plants as a nutrient. Liquid effluents are richer in nitrogen than in potassium, while denser ones, such as those obtained from straw and fermented grass, are relatively richer in phosphorus.

The process of anaerobic digestion takes place in a biodigester, a very simple type of technology that consists of a closed, hermetic and impermeable container, called a reactor. According to Solé and Flotats (2004), organic material is deposited to ferment in it (animal and human excrements, and vegetable waste except citrus fruits because they are acidifying) with a certain percentage of water. Through anaerobic fermentation bacteria produce methane gas and organic fertilizers rich in nitrogen, phosphorus and potassium. Cristiano, Miranda Zanetti and Zabaloy (2016) affirm that in this way, the contaminating potential of excrement is diminished and the generation of a type of clean and renewable energy is given, like biogas.

In order to obtain biogas, animal excreta, sugar cane cachaça, waste from slaughterhouses, distilleries and yeast factories, pulp and coffee husk, as well as vegetable dry matter can be used as raw material. This technique partially solves the demand for energy in rural areas, reduces deforestation due to the felling of trees for firewood, recycles waste from agricultural activity and is a "clean" and renewable energy resource.

Biogas can also be used as fuel in burners for heating chickens, pigs and other newborn animals, as well as for lighting by incandescent lamps. It can also be used as a single fuel for refrigerators, water heaters and grain and fodder dryers. Usually, it is used as second fuel in stationary or mobile explosion engines, which initiate with diesel or petrol (gasoline).

Organic residue of the biodigester, "the biol or biofertilizer", is presented as a slurry suspension in water, stabilized biologically and physicochemical, that is, it will not continue to be degraded biologically or it will degrade very slowly in the soil. After the anaerobic process of bacteria, it loses all the characteristic smell of rubbish.

Varnero Moreno (2011) exposes it has been proven that nitrogen, phosphorus and potassium remain in "the waste" after the fermentation process. Therefore, this fertilizer is richer than "humus" and has finer granulation than manure, which 
facilitates its penetration and mix with the soil. It is used to improve clay and sandy soils, which are poor in humus, and as a nutritive medium for vegetables under hydroponic cultivation and organic crops in greenhouses or fields. It can also be used as animal feed by mixing it to improve its "taste" with grains, cakes, honey and fodder, since the pure affluent has a concentration of amino acids similar to soybeans.

\section{STUDY CASE OF AN AGRARIAN FIRM IN THE CORFO REGION}

The case of a representative cattle producer from the Corfo region, Colorado River is presented in this section. This area is located in the south of the province of Buenos Aires in Argentina. The entire region is a fertile valley irrigated by more than $5,000 \mathrm{~km}$ of channels, which carry water from the Colorado River. This area is one of the main water basins of the country. The agricultural firm under analysis $\left(39^{\circ}\right.$ $30^{\prime} 33,0$ "S $62^{\circ} 41^{\prime} 22,1^{\prime \prime} \mathrm{W}$ ) has 300 hectares, infrastructure and equipment necessary to carry out the feedlot of 500 heads, such as: corrals, drinking troughs, feeders, a mixer with scales (to mix the fibers and chop rolls and bales in order to ensure an equitable distribution of food), a tractor, a shovel (to mix the food), a sprayer, a water tank and a work horse with scales.

The purpose of the firm is to fatten rearing calves of about $283 \mathrm{~kg}$ in confinement situation. The plan is to take them to a weight of $420 \mathrm{~kg}$, considering a daily weight increase of $1.470 \mathrm{~kg}$ in a cycle of 93 days (4 cycles per year approximately) in corrals with rammed earth floor with capacity for 500 heads (considering $10 \mathrm{~m}^{2}$ per animal). Pampuro (2015) says its strategic location has the advantage of having water resources, since this type of activity requires between 30 and 40 litres per day of water per animal.

Once carried to its final weight, cattle will be commercialized in the refrigerators of the zone to reduce the cost of the freight. An interesting aspect to note is that this type of activity, intensive in the use of resources (food, water, facilities, labour, land use, among others), frees land for agricultural use. This means that forage and grains can also be produced in the same land to feed the animals. Being located in the irrigation area also makes it possible to obtain higher yields per hectare, considering a mix of crops destined for the production of rations. The cost of food purchased is usually higher than ones of own production. However, depending on market conditions, the convenience of liquidating the farm and selling the grain (depending on relative prices) should always be evaluated.

Taking into account the firm previously characterized, the possibility of producing biogas from the treatment of effluents generated in the establishment (faeces + urine) will be analyzed. Being located in an irrigated area, the preservation of the 
water resource becomes vital for the region's growth. Law $N^{\circ} 14867$ (2016), that regulates this type of productive activity in the Buenos Aires province-sanctioned on November $30^{\text {th }}, 2016$ - constitutes the institutional framework to begin considering the case. Specifically, Articles 4 and 5 refer to the obligation of implementing an environmental impact study that should include, among others, a study of surface and groundwater resources, as well as a comprehensive plan for waste management.

According to Pordomingo (2014), taking into account digestibility of the bovine diet, a cow of $450 \mathrm{~kg}$ produces a daily average of $27 \mathrm{~kg}$ of wet excrement (urine and dung), with a variation of $25 \%$ (depending on climate, water consumption and type of diet). In this case, the firm, with 500 heads, produces 13.5 tons of manure per day, that is 405 tons per month. This manure, under anaerobic digestion treatment, generates biogas and biofertilizer.

Pordomingo (2014) expresses that, taking into account that from a ton of wet excrement from cattle it is possible to obtain $25 \mathrm{~m}^{3}$ of biogas, in this firm 10,125 $\mathrm{m}^{3}$ of biogas would be generated per month. According to Flotats (2010), the biogas from bovine manure is a poor gas, since the conversion efficiency is low. That is, for each ton of waste, between 20 and $30 \mathrm{~m}^{3}$ of biogas is obtained. On the other hand, $1 \mathrm{~m}^{3}$ of biogas is equivalent to $0.6 \mathrm{~m}^{3}$ of natural gas. Therefore, the $10,125 \mathrm{~m}^{3}$ produced monthly would be equivalent to $6,075 \mathrm{~m}^{3}$ of natural gas.

The aforementioned can be expressed in terms of the propane gas tanks used frequently in farms and agrarian firms. Each gas tank of $45 \mathrm{~kg}$ equals $58.4 \mathrm{~m}^{3}$ of natural gas. That is, the producer could replace some 104 gas tanks per month by treating the waste generated by their productive activity. In order to quantify and value 104 gas tanks, their average market price was taken as a reference: US 53 (November, 2019). The 104 tanks would represent a saving of US 5,512 per month. Although this does not mean that the producer necessarily has to use that amount of tanks (since, in any case, it will depend on the nature of the intensive energy production process that he carries out jointly with the basic activity, such as livestock), the result is useful as an example to show the convenience of treating biomass generated by the firm. According to Cristiano (2018), the value of the fertilizer obtained (the final digested substrate resulting from the anaerobic digestion process), equivalent to about US 5,700 per year should be taken into account.

Finally, it is interesting to mention the results of a recent study made by Chorkulak (2016), in which the potential of Argentina to generate biogas from confined meat production systems was evaluated. It analyzed the capacity for generating biogas considering all the establishments of cattle, pigs and poultry intensive production. Chorkulak (2016) affirmed that the capacity of the country to produce biogas, taking 
into account the current animal stocks in confinement systems, is 18,249 MW / h. This allows covering more than half of the country's current energy demand. Nevertheless, in this same work several cases were analyzed in which the profitability of different types of intensive productions that treated their organic waste by means of anaerobic digesters was calculated, which yielded different returns based on scale and applied technology (from high, middle and low).

\section{CONCLUSIONS}

The concern for the environment has led to institutional frameworks creation that tend to mitigate negative impacts generated by different productive activities. Both agricultural and agro-industrial sectors, which occupy a fundamental role in the Argentinian economy, are generators of a significant volume of organic waste (biomass). New production modalities -as is the case of the cattle activity that produces meat under the feedlot modality-show the need to carry out a treatment to these residues, making it possible to obtain biogas (which can be used by rural firms), impacting on a reduction in caloric energy cost for them.

Biogas is obtained from anaerobic digestion of organic waste processes that take place in biodigesters. On the other hand, digested or bio fertilizing substrate from the mentioned process can be used as organic fertilizer for the soil, since it is rich in macronutrients, such as nitrogen, phosphorus and potassium. This would also imply cost savings in terms of fertilizers. The proper treatment of waste contributes to reduce or even eliminate negative externalities that originate in production, thus protecting the environment.

Considering the described above, this paper presented a case study based on a farm which produces meat located in the south of the Buenos Aires province in Argentina). An alternative to reduce the amount of methane generated by the bovine sector is transforming bovine manure into caloric energy. The waste can be the input to produce a new output (biogas and biofertilizer) and turn the firm into a multiproduct one: now it not only produces meat but also energy. We determined that, from the effluent generated by 500 heads of cattle, it is possible to obtain $10,125 \mathrm{~m}^{3}$ of biogas per month, which could be sold (or used by the agrarian firm for self-consumption). It will impact the environment positively and benefit the firm.

This work has the limitation of not considering the initial investment or costs associated with the anaerobic digestion process. However, the most important topic is to present a new way to reduce externalities, turning the firm into a multiproductive one using a new technology.

Futures lines of investigations are related with bioeconomic and circular economy. 


\section{BIBLIOGRAPHY}

Aguilera Klink, Federico and Alcántara, Vincent (comps.) (2011). De la economía ambiental a la economía ecológica. Barcelona: CIP-Ecosocial, 408p.

Bragachini, Marcos; Mathier, Diego; Méndez, José; Bragachini, Mario and Saavedra, Alejandro (2014). Oportunidades del sector agropecuario y agroindustrial argentino para la generación de bioenergía en origen.

Bonilla Cárdenas, Jorge Armando and Lemus Flores, Clemente (2012). Emisión de metano entérico por rumiantes y su contribución al calentamiento global y al cambio climático. In: Revista Mexicana de Ciencias Pecuarias, vol. 3, n. ${ }^{\circ}$ 2, p. 215-246.

Chatelier, Vincent and Vérité, Robin (2003). L'élevage bovin et l'environnement en France: le diagnostic justifie-t-il des alternatives techniques? In: Productions Animales, vol. 16, n. ${ }^{\circ}$ 4, p. 231-249.

Chorkulak, Verónica (2016). Análisis de la capacidad de generación de biogás en Argentina a partir de residuos orgánicos producidos en granjas con sistemas de confinamiento. Thesis to apply for the title of Master in Environmental Administration Ambiental. Masters in Administración Ambiental, Instituto Tecnológico de Buenos Aires, Argentina, 88p.

Coase, Ronald (1960). El problema del coste social. En Aguilera Klink, Federico and Alcántara, Vincent (comps.) (2011). De la economía ambiental a la economía ecológica (p. 41-76). Barcelona: CIP-Ecosocial.

Cristiano, Gabriela (2018). Proyecto de desarrollo regional: un modelo basado en el tratamiento de residuos orgánicos. El caso de Corfo-Río Colorado. Thesis to apply for the title of Doctor in Economics. Doctorate in Economics, Universidad Nacional del Sur, Argentina, 180p.

Cristiano, Gabriela; Miranda Zanetti, Maximiliano and Zabaloy, Florencia (2016). Tratamiento de residuos orgánicos agropecuarios: abordaje teórico y empírico. Mar del Plata: Asociación Argentina de Economía Agraria, 22p.

Cuauhtémoc, Nava Cuéllar y Díaz Cruz, Antonio (2001). Departamento de Nutrición Animal, Facultad de Medicina Veterinaria y Zootecnia UNAM. Introducción a la Digestión Animal. http://www.produccion-animal.com.ar/informacion_tecnica/manejo_del_alimento/79-introduccion_a_la_digestion_ruminal.pdf

Di Paola, María Marta (2013). La producción de biocombustibles en Argentina. In: Fundación Ambiente y Recursos Naturales.

Flotats, Xavier (2010). Biogás y gestión de deyecciones ganaderas. In: SUIS, n. ${ }^{\circ}$ 72, p. 22-29.

Gruber, Steffen; Hilbert, Jorge and Sheimberg, Sebastián (2010). Estudio de caso preliminar de generación eléctrica de 1 MW con una planta de biogás de alta eficiencia. Una planta de biogás en base de estiércol animal en mezcla de silaje forrajeras de maíz en el marco agropecuario argentino. $\mathrm{N}^{\circ}$ Doc BC-INF-16-10, Argentina: INTA, 19p.

Hilbert, Alberto; Acevedo, Alberto; Donato, Lidia and Grasso, Daniel (2011). Programa Nacional de Bioenergía del INTA PNB. Argentina: INTA, 4p.

Instituto Nacional de Tecnología Agropecuaria (2014). El tratamiento de los residuos, clave en la gestión ambiental. Argentina: INTA. 
Johnson, Keith and Johnson, David (1995). Methane emissions from cattle. In: Journal of Animal Science, vol. 73, n. ${ }^{\circ} 8$, p. 2483-2492. DOI: 10.2527/1995.7382483x

Mas-Colell, Andreu; Whinston, Michael and Green, Jerry (1995). Microeconomic Theory. Nueva York: Oxford University Press, 998p.

Pampuro, Juan Manuel (2015). Diseño del feedlot bovino y aprovechamiento de sus efluentes. Thesis to apply for the title of Agricultural Production Engineer. Agricultural Production Engineering Program, Universidad Católica Argentina, Argentina, 35p.

Pigou, Arthur (1920). The Economics of Welfare. Londres: Macmillan, 876 p.

Pindyck, Robert; Rubinfeld, Daniel y Beker, Victor (2000). Microeconomía. Buenos Aires: Prentice Hall, 516p.

Pordomingo, Aníbal (2014). Efectos ambientales de la intensificación ganadera, Argentina: Proagro, Laboratorio Veterinario.

Recalde, Marina (2012). Una visión integrada del desarrollo del biodiesel en Argentina. In: Estudos Sociedade e Agricultura, vol. 20, n. ${ }^{\circ}$ 1, p. 188-216.

Rodhe, Henning (1990). A Comparison of the Contribution of Various Gases to the Greenhouse Effect. in: Science, vol. 248, n. ${ }^{\circ} 4960$, p. 1217-1219. DOI: 10.1126/science.248.4960.1217

Secretaría de Ambiente y Desarrollo Sustentable (2019). Tercer informe bienal de actualización de la República Argentina a la convención marco de las Naciones Unidas sobre el cambio climático. Buenos Aires: Secretaría de Ambiente y Desarrollo Sustentable, 279 p.

Senado y Cámara de Diputados de la Nación Argentina (2006). Ley 26093 de abril 19 de 2006. Régimen de regulación y promoción para la producción y uso sustentables de biocombustibles, $5 p$.

Senado y Cámara de Diputados de la Nación Argentina (2006). Ley 26190 de diciembre 6 de 2006. Régimen de fomento nacional para el uso de fuentes renovables de energía destinada a la producción de energía eléctrica, $9 \mathrm{p}$.

Senado y Cámara de Diputados de la Nación Argentina (2015). Ley 27191 de septiembre 23 de 2015. Modificaciones a la Ley 26190 que fomenta el uso de fuentes renovables de energía destinada a la producción de energía eléctrica, 11 p.

Senado y Cámara de Diputados de la Provincia de Buenos Aires (2016). Ley 14867 de noviembre 30 de 2016. Regulación de los establecimientos destinados al engorde intensivo de bovinos/ bubalinos a corral, 9p.

Sogari, Clotilde; Manfred, Reuss and Busso, Arturo (2000). Diseño de un biodigestor para obtener metano utilizando excremento de vacas y cerdos en una escuela agrotécnica. $4 \mathrm{p}$.

Solé, Francina and Flotats, Xavier (2004). Guía de técnicas de gestión ambiental de residuos agrarios. Lérida: Fundación Catalana de Cooperación, 94p.

Varnero Moreno, María Teresa (2011). Manual de biogás. Santiago de Chile: FAO, 119p. 